\title{
Rev Pungula Wellington Dingani - Leadership in the Corinthian Church in Phepheni, Eastern Cape, South Africa
}

NGTT DEEL 55, NO 1, 2014

\section{Barnard, Marcel}

Protestant Theological University (Amsterdam)

Stellenbosch University

Liturgical Studies, VU-University (Amsterdam)

\section{Nell, Ian}

Practical Theology, Stellenbosch University

\section{Mbaya, Henry}

Stellenbosch University

\section{ABSTRACT}

Local leadership is crucial in Africa. This article focuses on leadership in African Independent Churches, more specifically on the leader of a local congregation of the Corinthian Church, Rev Dingani in Phepheni, Eastern Cape. The article is composed of two parts. The first part is a portrait of Dingani, mainly from an emic (inside) point of view. After a biographical sketch, his ministry and liturgical leadership are outlined, followed by a portrait of Rev Dingani as a theologian. The second part, which mainly takes an etic (outside) stance, places this portrait in a wider context of leadership in African Independent Churches and sub-Saharan Africa as a whole. After indicating some general features of African leadership, the article focuses more specifically on two leadership styles: 1 . The humane-oriented and charismatic/value-based style. 2 . The participative and autonomous style. By distinguishing this emic and etic positions, we confront Western and African epistemologies, without reconciling them in advance. 


\section{INTRODUCTION}

Speaking of leadership in the context of sub-Saharan Africa, the big names come to your mind. Mandela, Tutu, Mugabe, Mobutu, Nujoma. They evoke the memory of good, bad or weak leadership, and of weak, strong or developing states and constitutional laws. However, particularly where 'the ideal of the nation-state remains forlorn' (Müller, 2011:5) and national leaders fail to meet the people's needs, local leadership is crucial. Local leaders guide, or fail to guide, the people through their daily needs. This applies to a large extent also for developing countries that until now have failed to sufficiently address the problems of poverty, unemployment and lack of facilities.

It is not by coincidence that post-colonial scholarly approaches emphasize locality. Within this context, the role of leadership in African Independent Churches 'deserves serious scholarly attention' (Müller, 2011:5). Involved in a project that included research of an African Independent Church - which we have previously published about - we therefore focused our attention on the local leader of the Corinthian Church in Phepheni, in the Eastern Cape. ${ }^{1}$ It became clear that his leadership is, inter alia, manifested as liturgical ritual leadership in this church. Social issues such as poverty and addiction are pre-eminently raised within the context of worship. The worship ritual can be considered as a source and a catalyst for mutual assistance, especially where the government does not offer such help or cannot offer it.

Scholarly terminology used to describe leadership behaviour derives mainly from Western language, routinely used in organizational psychology and sociology. When used in a religious context it requires important re-interpretations. Also, it does not necessarily reflect African views on leadership. Locality, and examination of the local, requires that primarily the local voice sounds. Our first questions in this article are therefore, how does the leading priest of the Corinthian Church in Phepheni understand his own leading role? And, how is that understanding to be understood

1 The research project ran from 2008-2011 and was funded by NRF, Grant number 73794 . The research was performed by a team of mainly South African and Dutch scholars, and led by Prof Cas Wepener, University of Pretoria. It is introduced in Wepener, C., Swart, I., Ter Haar, G., Barnard, M. (2010) The Role of Religious Ritual in Social Capital Formation for Poverty Alleviation and Social Development: Theoretical and Methodological Points of Departure of a South African Exploration. Religion and Theology. $17(1,2)$. pp 61-82; worship in the Corinthian Church is described and analyzed in Wepener, C., Mbaya, H., Barnard, M. (2011) Worship in the Corinthian Church (AIC) of Phepheni, Eastern Cape, South Africa. Studia Liturgica. 41 (2). pp 252-273; the start of the research is reflected on in Wepener, C. and Barnard, M. (2010) Entering the Field: Initiating Liturgical Research in an AIC. Acta Theologica. 30 (2). pp 192-210. 
against the background of his biography? Only then will we ask the question how this leadership can be understood in the context of broader perspectives on leadership in Africa, thereby using scholarly literature. As a consequence, the article is composed of two parts. The first part is a sketched portrait of the Rev Dingani, mainly from an emic point of view. The second part, which mainly takes an etic stance, places this portrait in a wider context of leadership in African Independent Churches and sub-Saharan Africa as a whole. By distinguishing this emic and etic positions, we confront Western and African epistemologies, without reconciling them in advance as noted by Ellis \& Ter Haar (2007:392).

\section{REV PUNGULA WELLINGTON DINGANI - A PORTRAIT}

We will sketch a portrait of Rev Dingani in three parts. First, we will present some biographical facts; then, we will focus on his ministry and more specifically on his liturgical ritual leadership. Eventually, we will portray Rev Dingani as a theologian. ${ }^{2}$ Other than a detailed biography, a sketch shows broken lines, vague spots and white, undesignated areas, but it shows an adequate picture. Some photographs, taken during the fieldwork, will contribute to the image of Rev Dingani in their own way. ${ }^{3}$

This biographical sketch is based on interviews with Rev Dingani, as well as on observations of the authors. We met Dingani in various places and circumstances, in his own village, usually after worship, as well as in Kokstad, the nearest town, on

2 With regard to methodology and authorship of this article: this section is mainly based on two interviews that the first author had with Rev Dingani, a long interview of nearly one-and-a-half hour on 24 December 2010 in Kokstad, KwaZulu-Natal, in the office of the Anglican Church. The third author of this article, who speaks isiXhosa as well as English, and who takes part in the project, translated the interview simultaneously. This interview was recorded. A short interview was performed on 25 December in Phepheni, Eastern Cape near Flagstaff, in the house of Rev Dingani. This interview was translated simultaneously by a local woman and also recorded. Transcripts of the English texts of the interviews were made, which were analyzed by the first author by means of Attribute Coding, Descriptive Coding and Structural Coding. The third author has checked the results. Additions were made on the basis of previous research, as it has been published in other publications (see references). In the taped interview Rev Dingani declines the offer of Informed Consent explicitly; he does not want to have insight in the article prior to publication. The interview data is stored at the Protestant Theological University, Amsterdam, Netherlands, in accordance with Dutch law. Other data of the research project is stored at the University of Pretoria, South Africa, as well as at Stellenbosch University, South Africa. The second author of the article provided background information regarding leadership in African contexts.

3 The first author of this article took all photos. 
the other side of the province border of the Eastern Cape, in the Sisonke District in KwaZulu-Natal. The town is about 25 kilometres from Phepheni and Dingani then travelled by bus to see us. In town, Rev Dingani was dressed in a shirt, sweater, a green jacket and blue pants (Photos 1,2). On his head he had, as usual, his cap with, what we would decode as 'Islamic' symbols: a palm tree and a crescent on a cupola according to Mbaya \& Chetty (2012). He himself, however, says that he does not know the interpretations of the symbols. He wears them because the founder of the church, Johannes Richmond, whose father was a Muslim, wore them. Dingani has a modern briefcase with him. In his role as liturgical leader he is dressed quite differently, as we will see later in this article.
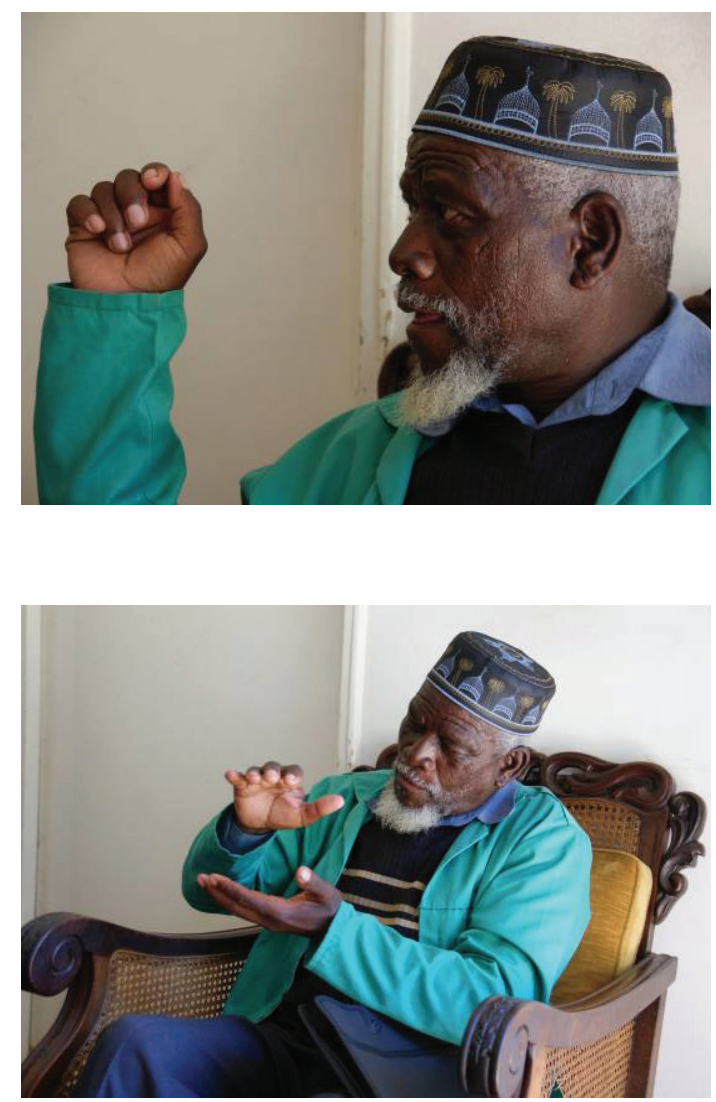

Personally, Rev Dingani is very much an accessible and expressive man. He uses wide gestures while he is speaking. He is also accessible and connected in a more technical sense: he has a cell phone. Remember, however, that Phepheni has no electricity, waterworks or sewage. Wireless networks ignore the lack of wired and pipe facilities. Dingani likes meeting the researchers who come to visit him, and when we met in Phepheni he has always shown generous hospitality. 
Rev Dingani belongs to the AmaXesibe ethnic group, and he speaks isiXhosa (mixed with IsiXesibe), but can also express himself in some Basic English phrases. Until recently most of the Xhosa people live in the Eastern Cape, but many have migrated to the Western Cape, especially in and around Cape Town, where they moved, hoping to find employment. This means that the social structure of traditional communities is broken because of the absence of these migrants. We will soon see that Dingani himself has also been a labour migrant for a substantial part of his life. Originally, Xhosa people were settlers, having cattle.

\section{Dingani's Life}

Pungula Wellington Dingani was born in the village of Emvalweni near the small town of Mount Ayliff. This is in the northern part of the Eastern Cape, roughly 125 kilometres inland from the Indian Ocean, where the land northward and westward begins to rise to the tops of the 'Draken Moutains' (Drakensberge). He was born on 29 March 1944. His parents were, as he told us, Christians and pastoral people, having cattle. He himself helped his parents with looking after the livestock. Until this day, the hills in this area are green, with cattle and sheep grazing in the pastures (Photo 3). Small villages of rondavels and square modest houses in pastels are scattered over the hills. He was baptized in a river and thus became a member of a church called African Church.

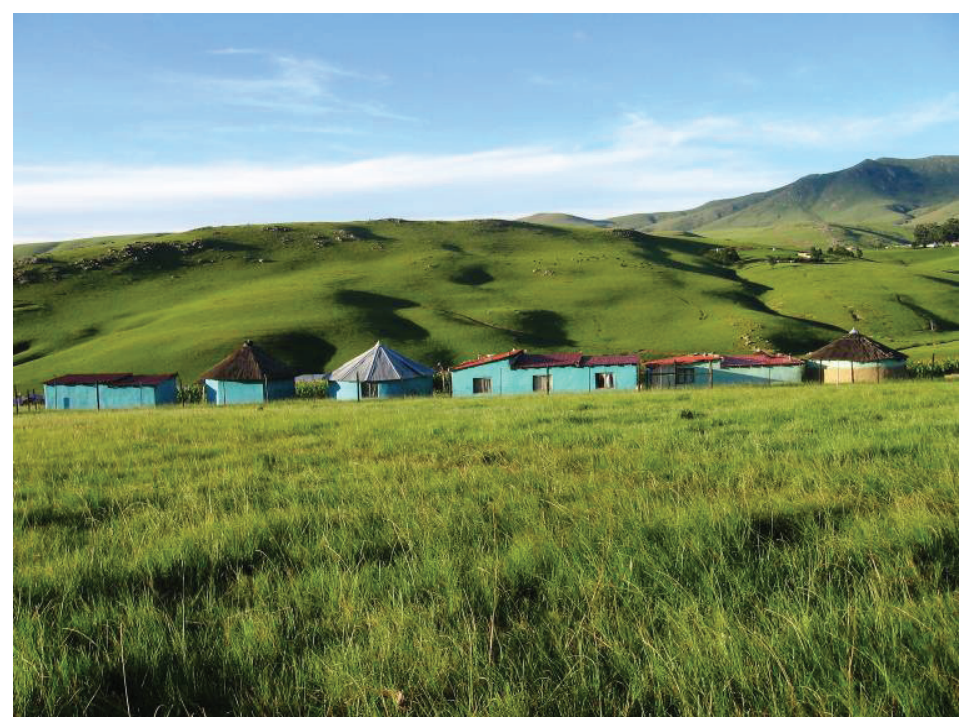

Dingani went to school as far as grade five. Then his parents died, and he could no longer afford to go to school. An aunt, a sister of his father, to whom he attributes an important role in his life, as we will see below, now further raised him. 
Later, Wellington Dingani worked in the coalmines around Johannesburg. He thus entered into a core industry of the South African economy (see Munnik, Hochmann, Hlabane \& Law, 2010). Mining shaped modern South Africa in an economic sense but has also moulded and is still moulding labour relations in the country. The apartheid regime used coal mining as 'an avenue for advancing Afrikaner capital' (Munnik, Hochmann, Hlabane \& Law, 2010:7). Labour circumstances of the black miners were severe, not to say gruesome, and unhealthy. Wages were low. The profits went to the white mine owners. Moreover, mining from its beginning, at the end of the $19^{\text {th }}$ century, disturbed social family structures, because young men left their native soil and their families for work in the Gauteng area. Conflicts surrounding the mining industries were one of the causes of the South African War. And mining labour is still a source of vehement social conflict in the 'new' South Africa, as the strike in the Lonmin mine in Marikana, near Rustenburg, in August 2012, shows. In this last conflict bullets from police arms killed 44 strikers. We find Wellington Dingani in the coalmines around Johannesburg from 1966 to 1981, in the harsh years of apartheid. This means that he left his family, his native soil and his cattle in the Eastern Cape and moved to Gauteng, looking for labour and money. He found mainly misery. We see a glimpse of the misery that he endured in his repeated remarks that he became addicted to alcohol and tobacco. Drinking and smoking seemed the only comfort in an otherwise bleak existence. He also tells us about his poverty. There were clearly periods of tough poverty, in which he had no money to buy trousers and other clothes, blankets and sheets. Even finding a wife appeared to be difficult, if not impossible, because of the dowry that traditionally has to be paid in African cultures.

Dingani tells us that he grew up as a praying person, and it is in this respect that he pays tribute to the aunt who raised him in his teenager years. 'She was a very prayerful person, all the time depending on prayer life'. In the reconstruction of his life story, he says that in his poverty 'the prayer was helpful, in the sense that through prayer people gave him things'. According to his understanding prayer made people give him things like blankets and also gave him his wife. He developed a longing to go to church for praying and becoming involved in church matters. In 1977 he experienced a call into the ministry.

His parents brought him up in the African Church mentioned earlier, which according to Dingani is very much like a Presbyterian Church. He himself, however, developed a preference for the Corinthian Church now. Dingani tells us that 'the Corinthians were very prayerful people. Knowing that he was going through difficulties, the Corinthians prayed for him and laid hands on him. His life improved: it was easier to get a job and he was getting money. From his point of view, his joining of the 
Corinthian Church goes along with the alleviation of poverty and the meeting of his wife. This is supported by the dates he gives, as he becomes a full member of the church in the year after he left the mines. He interprets his step into the church as a life-changing event, literally, as his poverty decreased and he became a married man. His wife plays an important role in the Corinthian Church in Phepheni nowadays. She plays a big drum in the services and is leader of the women guild. Rev Dingani and his wife got three children.

From then on, his ecclesial career rapidly developed. He started to read the scriptures and the minister urged him to become a full member of the church, which was effected in 1982. His first more or less official role in the church was that of doorkeeper, surveying whether everything in the church was in order, and welcoming people. In a next step he became an evangelist. This was affected by means of a ritual in which a goat is slaughtered. The blood of the goat is mixed with water, and thereafter the blood and fat of the goat, as well as oil, are smeared on the face of the newly installed evangelist. Then the sign of the cross is made with a staff, presumably that of the priest who presides over the service, and finally the meat of the goat are eaten. According to Dingani, the necessity of this rite is founded in an appeal to the Bible, more specifically, the Old Testament and the Law of Moses. With regard to the abundant slaughtering of animals in this church, the appeal is prominent, to a degree that Pauline laws are ignored to the advantage of the Mosaic laws.

Eventually, Wellington Dingani became the leading minister of the Corinthian Church in Phepheni. The complete, extended research team of the project of which this article is part, witnessed the last biographical fact to which we refer here. It is undoubtedly a highlight in Dingani's life. The ministry gave Dingani an opportunity to follow the three-years course of the Sokhanya Bible School in Cape Town, by means of distance learning and correspondence, as announced in the brochure on the KGA-website (2014). ${ }^{4}$ The school 'offers Biblical training to leaders and members of all kinds of Xhosa-speaking churches'. The only textbook that the students need is the Bible and no specific literacy level is required to subscribe to the courses. Students are coached in reading the Bible and in developing 'a socio-historical and biblical-theological frame of reference'. Dr Danie van Zyl, who previously taught at the University of the Western Cape, is lecturer at the school. The school is funded privately and by a commission that is affiliated with the Dutch Reformed Church. According to the brochure on the Internet, eighty to ninety students attend the

4 Also the following quotes are taken from this brochure. 
courses each year. Distance students are encouraged to shape a graduation ceremony according to their own insights.

Rev Pungula Wellington Dingani chose the visit of the extended research team in February 2010 as the suitable occasion to perform this ceremony (Photos 4, 5, 6). The graduation had to be performed by the leader of our research team. The bishop, Walter Zamindlela Njangule, in the picture in a blue gown, attended the ceremony. The service was held in a tent that had been especially erected for the occasion. Thus the researchers witnessed a ceremony after the service during which Dingani was clothed with gown and beret by Prof Cas Wepener from the University of Pretoria. The newly graduated minister received gifts from the parishioners as well as from the visitors. The gifts were mainly envelopes with money and blankets, the latter being a valuable present in the cold nights and sometimes also cold days in the Eastern Cape and KwaZulu-Natal.
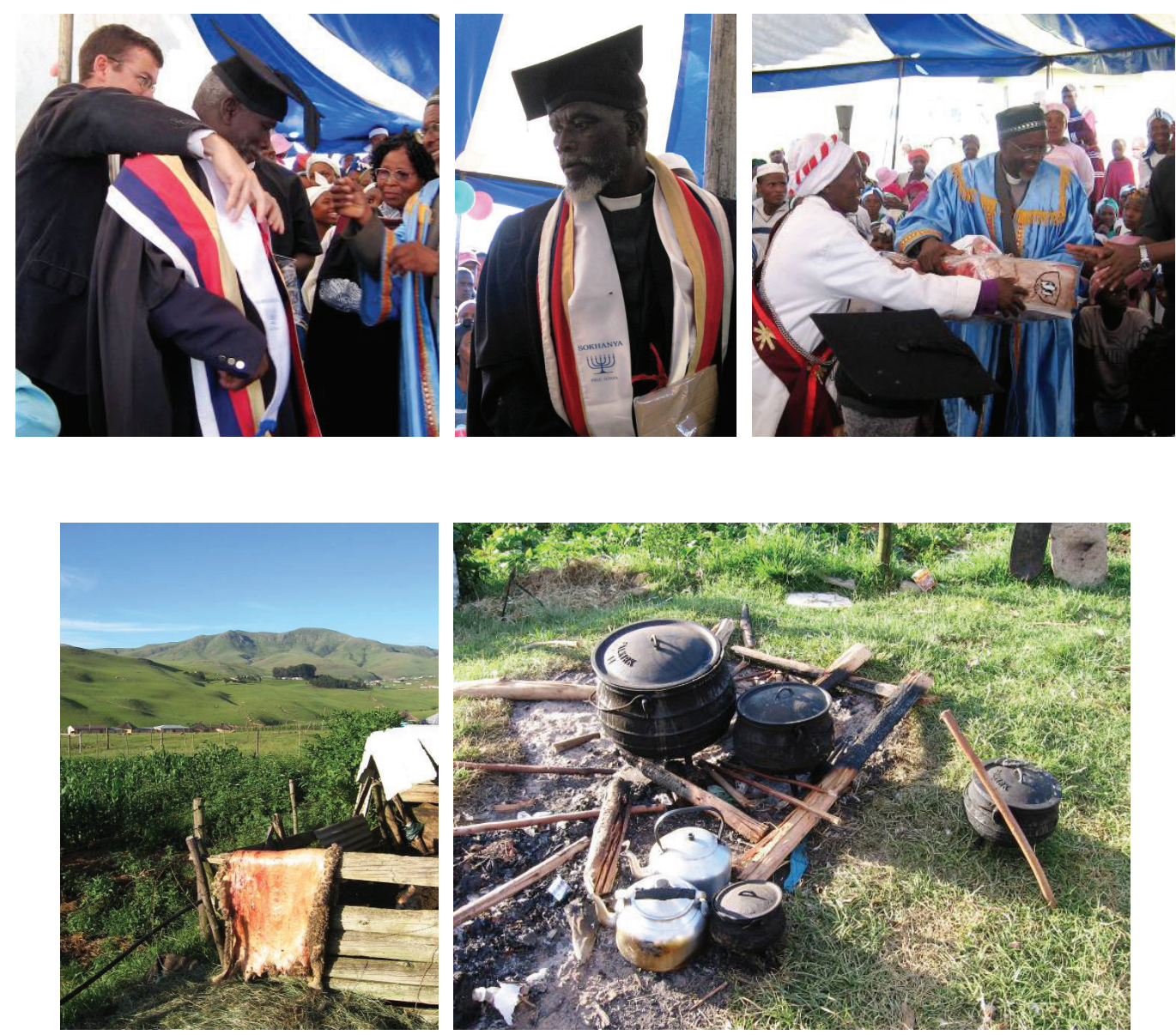
A sheep had been slaughtered that morning, and the party ended with a meal cooked in pots and pans on an open wood fire in the field for all attendees. The sheepskin hung to dry in the afternoon sun (Photos 7,8$)$. The researchers were treated as guests of honour. They ate with the minister in his house, while the villagers ate outside.

\section{Rev Dingani's ministry and liturgical leadership}

There can be no misunderstanding that Dingani is the leader of the Corinthian Church in Phepheni. He is the leading priest, although there are two other priests, one of whom is a woman. He represents the church in contacts with the various visiting academics. They deal with him. He is the host. After a service, they are received in his home for a meal, usually chicken and rice with some vegetables. On special occasions, a sheep is slaughtered. Also in the worship services Dingani is the leader. Leadership in the church is hierarchically structured. A regional bishop supervises the ministers, whereas the supreme leadership of the church is attributed to the widow of the founder, Archbishop Mrs Bestina Richmond. Now let us have a closer look at his leadership.

Dingani's call to the ministry, and thus to leadership, has developed gradually, as we have seen. A longing to go to church evolved into being a lector, which progressed into his being an evangelist and eventually a minister. Asked about his tasks as a minister, he first refers to the performing of the sacraments of baptism and holy communion, and also to the associated administrative task of providing baptismal certificates to the newly baptized people. This remark gives us insight into the organizational structure of this church, which is mainly paperless. Baptismal certificates are handed over to the ministers at the yearly festival of Isitshisa in Mlazi, Durban. Apparently, the Isitshisa is a kind of a hub in the Corinthian Church's network. There, not only spiritual and diaconal values are transferred, but also documents regarding church membership through baptism. This administrative structure is the responsibility of the minister.

Rev Dingani's leadership's role in worship is clearly marked by his liturgical vestments (Photos 9, 10,11, 12, 13, 14). A white shawl is wrapped around his hat and tied with one or three knots. He wears a green tunic with a clerical collar, and over this tunic an alb, of which he has at least two. He usually, but not always, goes barefoot during the services. He does not read from paper during his sermons, they seem to flow extemporaneously. When he reads from the Bible or from a Methodist book of worship, he wears spectacles. In worship he is the principal leader, but he encourages others enthusiastically to active participation in worship. 
BARNARD, MARCEL NELL, IAN MBAYA, HENRY
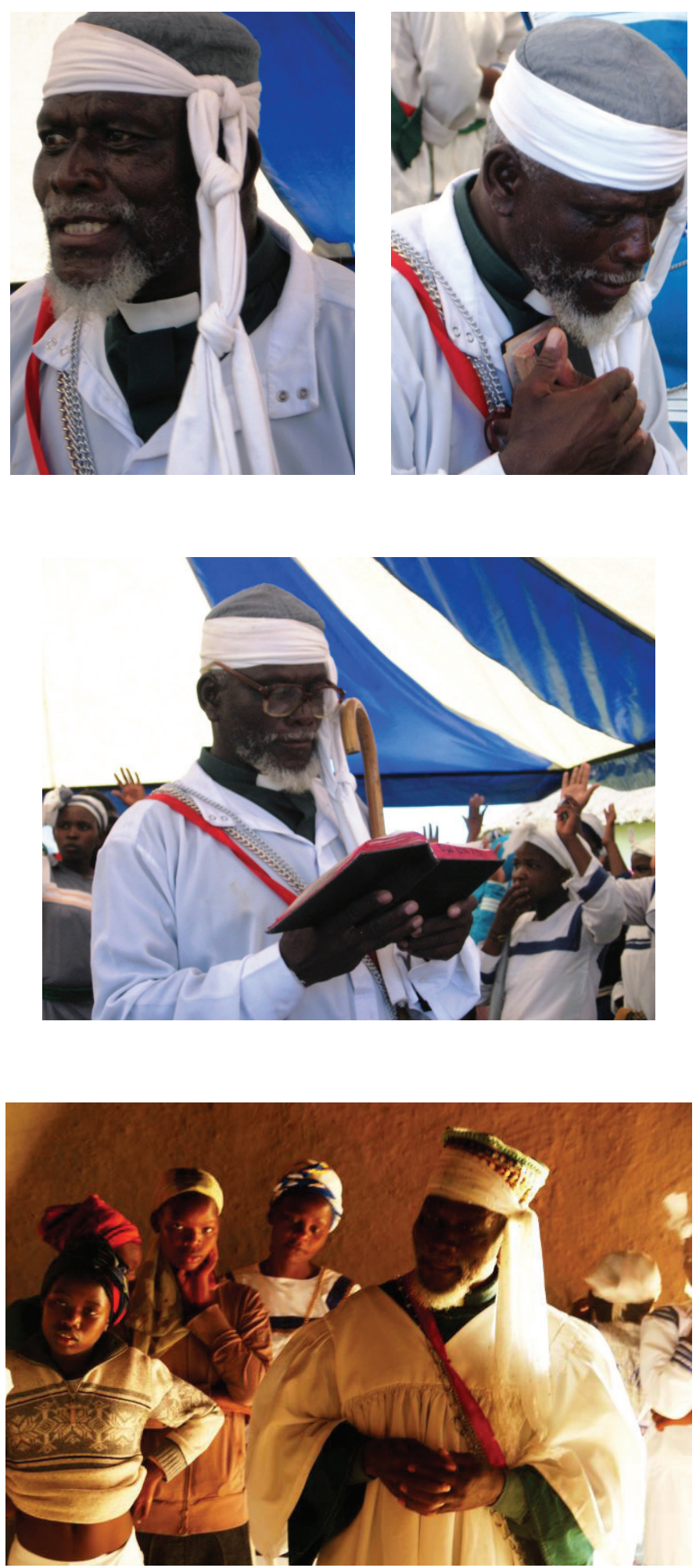

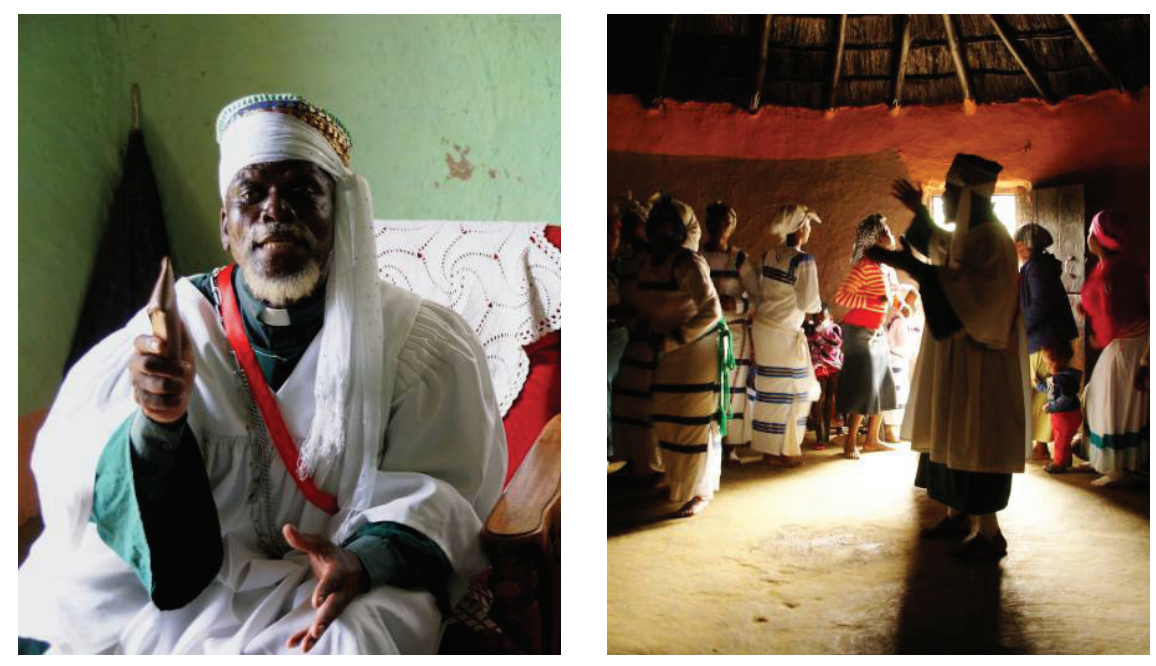

The pastoral care for the people in the church is another important role of the minister. Dingani frames this task in terms of the Holy Spirit, prayer and clarification. In a quote several aspects of this pastoral role are referred to:

(Translator:) ... now he is saying that during church, during worship, he prays for people to experience this power of the Holy Spirit. So the church is just the place where he encourages people to get involved in this, but when they go to their homes, they also experience this power of the Holy Spirit. Now in church sometimes, when they are praying, he has the revelation that some of the people are somehow closed, so he sometimes just slaps them... to open them.

Encouragement of the people is important in this regard, so 'that they can cultivate the spirit during worship. Prayer mediates this cultivation of the Spirit. The minister prays for the people and 'has to be very prayerful himself'. According to Dingani, this is also what people expect from him: they want 'to see you in the Spirit of God awakening. Leadership is first of all spiritual leadership, literary so: the leader must be filled with the Spirit. This aspect of being filled with the Spirit makes the leader a primus inter pares, for the content of his prayer is that the Holy Spirit will fall upon the congregation and that they will also be filled with the same Spirit. As a consequence, an important element in his leadership is that he encourages people to open up to the Spirit. This has to be understood literally. During service, it is revealed to him by the Spirit that some people are not opened to the same Spirit, and he has to physically slap them open. 
(Translator: ' The Holy Spirit is going to tell you that no, this person is not by himself. (...) There is something in behind. (...) You feel angry, that, feel angry! You feel cross. It is not you, it is something. It is something. I hit something. I don't see you. I hit something. Something go away! Go away! Go away, go away, something! I don't hit him. Hit a demon. It might be a demon! (...) Then, after that, you can see all the things are right. (...) Yeah, you must be careful with the spirits. (...) demons are so clever. (...) We try to keep the demons out of another person. If you are not strong and you are not (find?) amused by the Holy Spirit, that demon can come back straight to you'.

This slapping is a really forceful procedure, performed during the circle dances or prayers in the worship service. Dingani explains that in fact it is not he who is clapping, but the Holy Spirit. And it is not the person he is hitting, but 'something' or a demon. Therefore, a person full of the Holy Spirit will not feel pain when being slapped.

Being open to the Spirit is not limited to the church service, but also holds at home. The presence of the Spirit in the homes of the people is confirmed by them having dreams and visions sometimes. Here the role of the religious leader as hermeneutic comes to the fore. He interprets the dreams and visions. The nature of these visions or dreams is, says Dingani, dependent on the personal guardian angel. For instance, someone sees a man sitting on a rock, or someone dreams of a person getting into the water. People come to the minister to clarify the visions and dreams. He is the diviner. Dingani explains that the person getting into the water refers to baptism, and that the man on the rock is Jesus.

Dingani also showed a more autonomous leadership style in the way he registered the presentation of the gifts that we brought for him. We brought presents when we attended his graduation ceremony, and also during other visits. Usually, we took a book and collected some money as a kind of contribution for the food that we received, and as a contribution to the new church building that is planned. The foundations of this new church have already been laid, although we have seen no progress in the building process over the years. According to Dingani the construction materials are very expensive. As a rule, Rev Dingani wants us to present the smaller gifts, like books, in the worship service, whereas he prefers to take the envelope with some money in private. To do so in public, he says, 'would cause a lot of tension. (...) they [the congregation members - authors] think differently'. This leadership style caused a certain discomfort among researchers, who are oriented towards Western styles of leadership, because there seems to be no accountability of the gifts to the church community. However, we realize that there are no good structures in place 
for transparency; there is no formal building committee that supervises and plans the building activities, and bank accounts appear not to be in use.

\section{Rev Dingani as a theologian}

In this section we sketch Dingani as a theologian. We indeed consider him to be a theologian, albeit not in the traditional way that we use the word in academic discourse. His theological, as well as his general education, is limited. Leaders in African Independent Churches seem to construct a theology in a way 'that shows a real effort to be faithful to the Biblical text' and they 'work it out in detail in a "systematic" way', but many in those churches 'cling to a tradition which they cannot explain' (Van Zyl, 1996:230). On the basis of our interviews and observations, we will reconstruct Dingani's theological framework.

Reverend Dingani is first of all a pneumatological theologian. The Holy Spirit is in the centre of his theology, or, in other words, at the top of Father - Son and Holy Spirit. His pneumatology is closely connected to a liturgical theology, in which prayer forms the key. The Spirit foremost works in the members of the congregation, and in particular, but not exclusively so, in worship. Because the Spirit heals their lives and alleviates their poverty, it also has a societal impact. Conversely, poverty and disease have a spiritual component.

'Africa is indeed threatened by some massively destructive forces that can be quite precisely identified, including disease, debt and underinvestment. At the same time, however, many Africans also consider these conditions in a spirit idiom, seeing themselves as beset by evil forces that have a known material cause but that also have a spiritual dimension' (Ellis \& Ter Haar, 2007:397).

It is interesting that Dingani did not refer to Jesus Christ in the long interview that we had with him. Müller and Wepener, however, note that Dingani’s sermons have a 'distinct Christocentric hermeneutic' (Müller \& Wepener, 2011:5). On the basis of our observations and interviews, we have related dance and rhythm to the prayer to the Holy Spirit: dancing is closely connected to the evocation of the Spirit, and this is the rubric that most frequently returns in the liturgical orders. Dingani confirms this: the drumming 'gives you power and is very much connected to the Holy Spirit, to the descent of the Holy Spirit'.

The work of the Spirit foremost favours the members of the church. This work refers to healing and alleviation of needs. Healings in and through the worship services are directly attributed to the Spirit - in the interviews that we had with Rev Dingani he refers in this regard to the healing of his own backache. The broader society 
comes into view via the people prayed for. By praying for them needs become social: through prayer needs are shared among the members of the church. This prayer also confirms the fact that in African epistemology needs have a spiritual dimension that can be cured through prayer. It is in this indirect way that society comes into view through the worship rituals.

Corinthians for example hold true that in their church you do not smoke or drink. If they nevertheless do, they are being prayed for, and in that sense the church contributes to a healthy society. Conversely, the Spirit that comes through prayer can cure smoking and drinking addictions. Poverty is addressed in the same way. The church prays for poor people, so poverty becomes public and can be alleviated through reciprocal help. The yearly Isitshisa festival has a strong diaconal element and serves as a lesson for the participants and their local congregations to do good to the poor and needy. In so far, this theology of the Spirit that comes through prayer stimulates social bonding, whereas structural analyses of poverty and addiction in a more western sense seem to be absent. Questioned whether he is involved in politics, Dingani says that he is not much interested in it and expresses no great trust in political leaders. The names of South Africa's most prominent leaders, even the national Xhosa leaders such as Nelson Mandela, Thabo Mbeki, and Desmond Tutu, are virtually absent in the conversations with Rev Dingani.

The theological leadership of Rev Dingani requires a precise discernment of the different spirits that hover around and through the empirically observable world: the Holy Spirit, the spirit of the church founder and the other spirits have to be distinguished very precisely. The Holy Spirit is closely connected in a kind of cooperation to the spirit of the late founder of the church, whereas the spirits of the ancestors and also, as we have seen, the demons, are clearly distinguished from the Holy Spirit and the spirit of the founder, in the theology of Dingani. These categories of the spiritual world are distinguished, but at the same time juxtaposed, and in the case of the demons opposed. Besides the Holy Spirit the spirit of the founder of the Corinthian Church is evoked in worship. The spirits of the ancestors play no part in public worship, according to Dingani, but in individual services, so-called ladi. These are special services in case of individual problems. Dingani explains that in such a service the person who is in trouble, while the minister prays for the person with the problem evokes the spirits of the ancestors. The spirits come to assist the person and to sort out the problems. The different spirits are connected to different colours of candles. In public worship the white candle on the table refers to the Holy Spirit, in ladi-services candles in different colours are placed on the floor.

Dingani's references to the Bible are rather loose or at least difficult to systematize. Müller and Wepener speak of a 'spiritualising hermeneutic' (Müller \& Wepener, 
2011:5). Yet, his theological education was focused on the Bible. Dingani appears to consider the Scripture a predicate of the Holy Spirit: the Bible is 'read and understood under the direct inspiration of the Holy Spirit and then applied directly without use of interpretative skills' (Müller \& Wepener, 2011:5). Sometimes, Dingani expresses uncertainty about what the Bible says. When talking about angels, he says: (translator) 'maybe he is saying something which is not in the Bible, I don't know he does not know either'. Sometimes, however, he is very resolute on hermeneutic choices and shows a certain freedom towards the literal text or at least does not problematize contradictions within the Scripture itself. The sacrificing practices of the church are, he says, strongly rooted in the Mosaic law. So are the dressing codes. They are performed according to the old-testament laws, and to the detriment of Paul, - according to Dingani, rightly so. Without further reflection he says that in this regard 'the Jewish custom' is followed. Sacrifices are in a Mosaic way seen as a way to communicate with and to express thanksgivings to God, but also have a bonding effect on the community.

\section{LEADERSHIP IN THE “AFRICAN CONDITION”}

\section{Features of sub-Saharan leadership styles}

Regarding sub-Saharan African leadership styles, Peter Northouse $(2010)^{5}$ found a prevalence of a 'humane-oriented leadership', in which '(c)oncern for family and friends is more important than concern for the self' (Northouse, 2010:347). Concerning the sub-Saharan Africa Leadership Profile he writes:

'An ideal leader is modest, compassionate, and sensitive to the people... In addition, they believe a leader should be relatively charismatic/valuebased, team orientated, participative, and self-protective. Leaders who act independently or act alone are viewed as less effective in these countries. In short, the Sub-Saharan Africa profile characterizes effective leadership as caring leadership' (Northouse, 2010:353)

5 Northouse makes use of House, R.J., Hanges, PJ, Javidan, M, Dorfman, PW \& Vipin Gupta (eds.) (2004) Culture, Leadership, and Organizations: The Globe Study of 62 Societies. Thousand Oaks/ London/ New Delhi: SAGE Publications. Northouse has identified nine cultural dimensions that determine the character of leadership. On the basis of these markers he has proposed six perspectives of leadership behavior, which in different compositions characterize leadership in ten 'clusters of world cultures'. SubSaharan Africa is one of these clusters. The research for this cluster was performed in Zimbabwe, Namibia, Zambia, Nigeria and South Africa (black sample). 
Thus, in a hierarchical order, the following features characterize effective leadership: humane-oriented, charismatic/value-based, team-oriented, participative, selfprotective, autonomous (Northouse, 2010:354). Northouse's findings correspond with the conclusions of Van Zyl, Dalglish \& Lues (2009:32), a group of South African researchers, although they are much more critical of many of the negative characteristics found within African leadership in general. However, they also refer to features like spiritual collectivism, inclination towards consensus, humility and helpfulness, an inclusive system, perpetual optimism and a belief in superior forces as part of the African cultural value system.

We take these features as a generalization of Sub-Saharan Africa style of leadership and use them as a heuristic instrument in probing into the leadership of the Corinthian Church.

\section{Humane-oriented and charismatic/value-based leadership in the Corinthian Church}

From an emic perspective successful leadership in the Corinthian Church is primarily characterized by charisma and the work of the Holy Spirit. From an etic perspective it is particularly striking how successful leadership seamlessly joins traditional African values and social structures. The Corinthian Church is a church of the poor and for the poor, thus existing within the contexts of poverty and of governments that are unable to meet the basic needs of the people. Taking the etic and academic view, the leadership style in this African Indigenous Church primarily shows a human orientation. Charisma/value-based and participative leadership styles, together with a more autonomous style, represent strong secondary characteristics.

It was the vision and initiative of the church's founder, Johannes Richmond, to give the blind a central place in the yearly Isitshisa festival (Barnard, Mbaya \& Wepener, 2014). They, as well as other needy persons who are normally excluded socially, benefit from the generosity of the Corinthians when they try to give them equal opportunities and attempt to transform the social conditions of the blind. The festival, similar to the local services, is performed to re-establish solidarity in a broad sense, that is, including friendliness, brotherhood, et cetera. In interviews with the wife of the founder, the present archbishop of the church, Mrs Bestina Richmond, strongly expressed to believe that the leadership of the Church has derived from divine calling in her late husband, prompted by the Holy Spirit. She is of the opinion that the founder is said to have had a very special calling from God as prophetic and charismatic figure. It is observed that in Zionist churches - to which the Corinthians do not count themselves, but which are big African indigenous churches - the bishop is a central figure, and "is understood to have supernatural powers to intercede on 
behalf of his followers" (Müller, 2011:189). Charisma is clearly needed to enhance an attitude of friendliness and brotherhood.

The emphasis on brotherhood or friendship can be evaluated from the perspective of African worldviews and values that emphasize the importance of the extended family. The organizational structure of the church and of its leadership hierarchy is focused on the transfer of not only spiritual but also diaconal values. Thus African Independent Churches and their leadership "constitute a form of parallel nationality" (Müller, 2011:5). Whether this process of value transfer succeeds, is dependent on the charisma of its leaders and their commitment to common values.

By analogy with the national leaders, also local leaders such as Rev Dingani claim to be driven by the Spirit. Dingani also sees it as his mission to heal and alleviate needs of the congregation. His charisma, that is, in his self-understanding, his being led by the Holy Spirit, is leading in this assignment. According to his own views, he shapes his mission mainly in the context of liturgical ritual by identifying needs, that is by identifying demons and other hindrances that keep people closed for the Spirit, and opening them to the Spirit, which in turn heals and provides for their needs. From a more distanced academic point of view, he can be said to join traditional African worldviews of richly populated spiritual realms and traditional African values of the extended family and ubuntu. He gives people their self-esteem back in a context of humiliating poverty and a failing government. The key to unlocking the enigma of the success of Zionist churches is 'residing in its ability to integrate and make whole the various fragmented realities that constitute contemporary South African society' (Müller, 2011:5). The striving for human wholeness, especially among people experiencing marginalization and deprivation on account of poor living conditions, is also in the centre of the activities of the Corinthian Church.

Hence, the interface of religion and culture is aimed at in these churches, and the success of leadership is connected with the extent to which they successfully perform such integration. As a consequence, the success of leadership is dependent on the extent to which the liturgical ritual is really African. On the other hand, leadership is dependent on the recognition that the leader is called, created and guided by the Holy Spirit.

\section{Participative and autonomous leadership in the Corinthian Church}

We find the most important aspect of the participation in leadership activities in the Corinthian Church in the ritual and liturgical setting. The rituals characterize the leadership role of the minister, for instance as the enactor of the rituals and celebrant of sacraments. He also encourages participants to participate actively in the liturgy. 
One of the outstanding features of performing the rituals within the liturgical setting is of course the participation of all the participants in the sanctuary through rhythmic dancing, blowing of trumpets, prophecies, praying and many other ritual activities. Further, Rev Dingani is not the only priest in the church in Phepheni, two others, one of who is a woman, accompany him. However, upon receipt of some of the gifts, we have observed deliberately non-participative leadership behaviour.

It is significant that the wife of the founder is revered as 'woman leader' [umongamelikazi] and is regarded as the custodian of the traditions of the church with a special role to play, as we discovered in another interview. It is she who brought in the golden iron sword [induku], which bestowed authority on the bishop to preside over all the following proceedings. It is clear that the future of the Corinthian Church depends on the extent to which a member of the family in this case the wife of the founder - sees to it that the traditions of the church are performed in terms of the rulings prescribed by the founder, e.g. the right sacrifice for the isitshisa ritual.

Leadership is also autonomous in the sense that it is hierarchical, where the power is distributed in a command line of authority. From this observation, it can be concluded that succession is critical, as it has to ensure continuity of the tradition and therefore its legitimacy and authenticity. Because of this, the right rituals must be performed correctly to ensure legitimacy of authority. In the Zionist Christian Church we find a similar 'history of dynastic leadership': 'one is struck by how much of it seems to be about the Lekganyane family, rather than about the ordinary people making up the church' (Müller, 2011:15).

\section{BIBLIOGRAPHY}

Barnard, M., Mbaya, H. \& Wepener, C.J. (2014) Blessing, Burning and Burying. Social Cohesion in Churches in South Africa. In Gräb, W. \& Charbonnier, L. (eds.). The impact of religion on social capital formation and social development in different cultural contexts. Entering the field in an international and interdisciplinary perspective, Berlin / Münster: LITVerlag, pp 109-126.

Ellis, S. \& Ter Haar, G. (2007) Religion and politics: taking African epistemologies seriously. The Journal of Modern African Studies. 45 (3). pp 385-401.

House, R.J., Hanges, P.J., Javidan, M., Dorfman, P.W. \& Vipin Gupta (eds.) (2004) Culture, 
Leadership, and Organizations: The GLOBE Study of 62 Societies. Thousand Oaks/ London/ New Delhi: SAGE Publications.

KGA-website. (2014) Sokhanja Bible School Brosjure. [Online] Available from: http://kga.org.za.mytempurl.zadns.co.za/wp-content/uploads/2013/08/Soklhanya Brosjure.pdf [Accessed 2nd April 2014].

Mbaya, H. \& Chetty, I. (2012) Creativity and imagination: Symbols, ritual performance and identity formation in the Corinthian Church of South Africa. Scriptura 111. pp 569-582.

Müller, B.A. \& Wepener, C.J. (2011) Applying grounded data theory to data collected through participatory action research on African Independent Churches' liturgical rituals: A comparative study. HTS Teologiese Studies/ Theological Studies 67 (2).

Müller, R. (2011) African Pilgrimage: Ritual Travel in South Africa's Christianity in Zion. Farnham, UK/Burlington, USA: Ashgate.

Munnik, V., Hochmann, G., Hlabane, M. \& Law, S. (2010) The Social and Environmental Consequences of Coal Mining in South Africa: A Case Study. (January). Cape Town, South Africa: Environmental Monitoring Group/ Amsterdam, The Netherlands: Both ENDs, pp 5-7. [Online] Available from: http://woek.de.dedi1054.your-server.de/web/cms/upload/pdf/kasa/publikationen/ munnik 2010 the social and environmental consequences of coal mining in sa.pdf. [Accessed: $20^{\text {th }}$ September 2012].

Northouse, P.G. (2010) Leadership: Theory and Practice. Thousand Oaks/ London/ New Delhi: SAGE Publications.

Van Zyl, D.C. (1996) Zionists Doing Theology. In Kitshoff, M.C. (ed.). African Independent Churches Today (=African Studies 44), Lewiston/ Queenston/ Lampeter: The Edwin Mellen Press.

Van Zyl, E.S., Dalglish, C. \& Lues, L. (2009) Leadership in the African Context. Cape Town: Juta \& Co Ltd.

Wepener, C. \& Barnard, M. (2010) Entering the Field: Initiating Liturgical Research in an AIC. Acta Theologica. 30 (2). pp 192-210. 
Wepener, C., Mbaya, H. \& Barnard, M. (2011) Worship in the Corinthian Church (AIC) of Phepheni, Eastern Cape, South Africa. Studia Liturgica. 41 (2).pp 252-273.

Wepener, C., Swart, I., Ter Haar, G. \& Barnard, M. (2010) The Role of Religious Ritual in Social Capital Formation for Poverty Alleviation and Social Development: Theoretical and Methodological Points of Departure of a South African Exploration. Religion and Theology. 17 (1,2). pp 61-82.

\section{KEYWORDS}

Leadership

Africa

African Independent Churches

Biography

\section{TREFWOORDE}

Leierskap

Afrika

African Independent Churches

Biografie

\section{CONTACT DETAILS / KONTAKBESONDERHEDE}

Marcel Barnard

Professor of Practical Theology and Liturgical Studies

Protestant Theological University (Amsterdam),

VU University and

Stellenbosch University

The Netherlands and South Africa

mbarnard@pthu.nl 